\title{
Exploitation of Pragmatic Aspects in Indonesian Humorous Discourses
}

\author{
I Dewa Putu Wijana \\ idp_wijana@yahoo.com \\ Faculty of Cultural Studies, Universitas Gadjah Mada
}

\begin{abstract}
This paper is intended to analyze and describe various pragmatic aspects exploited by humorous discourse creators in creating jocular texts in Indonesian. By assuming that nearly all jokes are created through a non bona fide process of communication, in which cooperative and politeness principles are intentionally violated in various ways, there must be extensive exploitations of pragmatic aspects. The examples are many kinds of speech acts, presupposition, pragmatic implicature, etc. found in Indonesian humorous discourse to create activities. All of these aspects so far have not been seriously studied by Indonesian linguists, especially whose works concern with humorous discourses.
\end{abstract}

Keywords: humor, discourse, text, pragmatics.

\section{Introduction}

Humor, which is commonly regarded as something related to trivial matters, certainly plays a very important role in human life because of its capability to release people from various kinds of tension they have faced in conducting their daily activities. The people's misleading and belittle views towards humor might directly cause the rareness study of humorous discourse found in any world language compared to the studies of other aspects of language. As far as Indonesian studies of humor are concerned, several investigations can be mentioned. Those are Wijana (1995) and Noerhadi (1992) that concern Indonesian cartoon discourse, and Wijana (2015) and Surana (2015) respectively discussing the Indonesian political humors and Indonesian humorous sticker discourse. Even though the study of Wijana (1995) and Surana (2015) is conceptually framed by sociolinguistic and pragmatic
Theories and the objects of study are the shape of brief monologs or dialogs, these studies are mostly full of analysis of play upon words, such as phonological substitution and permutation, lexical and grammatical ambiguities, synonymy, antonym, euphemism, metonymy, etc., which are intentionally exploited by the cartoonists and sticker creators in arousing the comic effect of their creations. The presence of pictures or illustrations either in cartoons and stickers, which are expected to provide contextual back ground to the cartoon and sticker discourse, in fact does not help much the creators create humorous discourses on the basis of higher hierarchical pragmatic levels. Meanwhile, the study of Noerhadi (1992) and Wijana (2015) tend to focus on script oppositions created by the cartoonists and jocular discourse creators without paying much attention to the role of 
linguistic and pragmatic aspects

developing the wholeness of discourse.

Based on such conditions, this paper aims at finding out the exploitation of pragmatic aspects of higher level, such as speech act, pragmatic implication, and presupposition by the Indonesian humorous discourse creators. This study is considered to have a significant role in enhancing our comprehension towards the importance of those pragmatic aspects in any verbal communicative processes. Therefore, any types of humorous texts essentially are important language teaching materials to use by any party (teacher or lecture), especially to explain linguistic problems of any levels that make the teaching situation more interesting, alive and enjoyable (Wijana, 2011: 485-503).

\section{Conceptual Framework}

Conceptually usual (non-humorous) discourses are different from the humorous ones. The first is developed by certain assumptions that the text producers (writer or speaker) and the receivers (listener or reader) are tightly bound by communicative rules in which both parties will behave naturally to succeed the communication process, and no party intends to mislead the other (Allan, 1986, 3). This condition is called bona fide process of communication (Raskin, 1994, 103).

From Grice's theoretical view point, the so called bona fide process of communication is marked by the obedience of interlocutors towards four conversational maxims, i.e quantity, quality, relevance, and manner maxim (Grice, 1975: 45-47). In addition, in such a situation the interlocutors should also consider the implementation of interpersonal politeness maxim which consists of six sub-maxims. Those are tact maxim, generosity maxim, approbation maxim, modesty maxim, sympathy maxim, and agreement maxim (Leech, 1983, 132). Speakers can flout or break their obedience towards those maxims as long as there are some reasons that underlie that violation. In other words, there are always implicatures of any violation towards the cooperative principles and the politeness principles.

In humorous discourses, comic effect achievement is the main reason for the violations. As the results, various types of puns, such as inter-lingual pun, malapropism, spoonerism, tongue twister, printing error, etc. can be found in the use of language (Apte, 1985. 181-187). As what will be proved in this paper, play upon words must not be the only way used by the humorous text creators, other aspects of pragmatic use of language can also be exploited in order to flout the cooperative and politeness principles have been mentioned above.

\section{Method of Investigation}

This research begins with the data collection extracted from Indonesian humorous story books. The data presented in this paper are those that exploit pragmatic aspects as the source of their humor. The pragmatic aspects are then classified whether they belong to speech act with its sub-categories, pragmatic implicatures, presupposition, or others. The Indonesian humorous discourses are presented together with their English translation.

\section{Results}

After examining the data carefully, there are at least three aspects of pragmatics that are often exploited by the humorous discourse creators. Those are speech acts, presupposition, and pragmatic implicatures which will consecutively be discussed below.

\section{Speech Act}

Speech act is the most important topic concerned in pragmatics because all utterances which constitute objects of pragmatics are produced through speech acts. Speech act is various possible acts performed by the speaker in uttering speech. In order to identify what kind of speech act an utterance belongs to, the utterance must be analyzed together with its context. Extra linguistic factors such as speaker, hearer, 
spatiotemporal setting of the utterance, words preceded and followed the utterance, etc. are an inherent parts of the utterance context (Leech 1996, 13; Sperber \& Wilson, 15-16). Indonesian humorous text creators some time exploit sentences which have unclear contextual situation, such as shown in anecdote (1) below.

(1) Romo Dr. Haryatmoko dalam suatu pelatihan Metodologi Penelitian Kualitatif dan penelitian filsafat bagi dosen Filsafat UGM tahun 2009, memberi contoh yang bagus bahwa teks itu kadang otonom. Suatu saat ada seorang sopir truk dari Jogja menuju ke Bogor. Karena capek, maka dia beristirahat di tepi jalan dan tidur di mobilnya. Baru beberapa saat dia tidur, jendela pintu truknya diketuk orang. "Pak, jalan menuju ke Bogor itu lewat mana, ya?", tanya pengetuk pintu yang ternyata pengemudi lain yang hendak ke Bogor. Dengan agak berat hati dia menjawab, "Bapak terus saja ke depan, dan setelah bertemu perempatan belok kanan." Setelah mengucapkan terima kasih, pergilah sang penanya tersebut. Kejadian ini berulang sampai tiga kali dengan pengendara yang berbeda. Akibatnya sang sopir tidak beristirahat. Karena betul-betul ingin istirahat, tetapi tidak bisa, karena selalu ditanya ke mana jalan menuju ke Bogor, maka dia mengambil kertas dan menuliskan, "SAYA TIDAK TAHU JALAN MENUJU BOGOR", kemudian dia tempelkan kertas itu di pintu samping truknya dengan harapan tidak ada lagi orang yang bertanya tentang jalam menuju ke Bogor. Kembali dia melanjutkan istirahatnya. Namun baru beberapa saat kemudian, kembali dia dikejutkan oleh suara pintu truknya yang diketok orang. Anehnya orang itu tidak merasa bersalah justru dengan bangga mengatakan. "Mas, Anda tidak tahu, ya jalan menuju ke Bogor? Saya tahu, yaitu Anda ke depan setelah bertemu perempatan belok kanan..." Anda dapat bayangkan betapa jengkel sopir tadi.
'Preacher Dr. Haryatmoko in a Qualitative and Philosophy Research Methodology Training for UGM faculty of philosophy lectures, gave a good example that a text sometimes was autonomous. One time there was a truck driver went to Bogor from Yogyakarta. Because of long way travel, he felt very tired, and took some rest. He was asleep in the truck. But, not long after, someone knocked the door. "Sir, where is the road goes to Bogor?" Then, he reluctantly answered, "You just go straight away, and after intersection turn left." Apparently, he was another truck driver who would go to Bogor." After saying thank you, that driver was gone. The same events happened three times with different drivers. Because he really wanted to take a rest, and was always disturbed by someone who wanted to go to Bogor, he took a piece of paper, and wrote "I don't know the road goes to Bogor." and stick it in one side of the truck. He continued his sleep. But, not so long after, someone knocked the door again. Strangely, the person did not feel any guilty, but proudly told: "You really don't know the road to Bogor, do you? I know it. You go straight way, and turn right after the intersection." You all can imagine how annoyed the driver was.

The existence of autonomous text in (1) is due to Saya tidak tahu Jalan ke Bogor 'I don't know the road goes to Bogor' has lost its context. Thus, it can be interpreted as the act of indirect information requesting "Please tell me, where the road to Bogor is" even though the writer intends his utterance to be an indirect forbidding/prohibiting which means "Don't disturb me because I don't know the road to Bogor."

Different from (1), humorous discourse (2) exploits indirect and non-literal speech acts, namely the speech act formed by sentence of the different mode from its intention and has opposite meaning to the words which construct the sentence (Parker \& Riley, 2014, 42-43). In (2) the teacher's non literal command to be silent is literally taken by her students. 


\section{(2) TERLALU TENANG}

Seorang guru kelas IV harus meninggalkan kelasnya selama beberapa menit. Ketika dia kembali, dia begitu terkejut karena semua murid di kelasnya sangat diam dan tenang, tidak seperti biasanya jika ia masuk ke dalam kelas tersebut. Murid-muridnya pasti sedang ribut dan bertingkah seenaknya. Tapi kali ini murid-muridnya sedang duduk sangat manis.

Guru yang masih sangat terkejut itu berkata, "Wow, selama aku mengajar kalian, aku tidak pernah melihat kejadian seperti ini sebelumnya. Ini sangat mengejutkan. Tapi tolong beritahu aku, ada apa sebenarnya dengan kalian? Mengapa kalian sangat tertib?

Akhirnya setelah beberapa saat guru menanti jawaban, Sally salah satu muridnya berbicara. "Baiklah, ibu guru pernah mengatakan kepada kami, jika ibu masuk ke kelas kami, dan mendapatkan kami sedang duduk tenang dan tertib, ibu pasti akan langsung terkena serangan jantung."

\section{TOO QUIET}

A four grade class teacher had to leave her class for several minutes. When she came back, she was so surprised that all students were quiet and silent not as usual when she entered that class. All students that were noisy and behaved as they wish, but that time they sat nicely.

The teacher who was still surprised, said, "Wow, as long as I teach you all, I have never seen the situation like this before. This is really surprising me. But, let me know, what's wrong with you? Why are you so quiet and obedient?

Finally, after waiting for a while, Sally, one of the students answered. "All right, you ever said to us, if you entered our class, and found us sitting quietly and nicely, you certainly would get heart attack".

In (2) it is described that on one side, the students do not comprehend their teacher's non-literal utterance which the teacher will be very happy to see her students calm and quiet. On the other side, the naughty students show that the unusual behavior is intended for their teacher's getting heart attack. Discourse (3) is intended to criticize some Indonesians who are too obedient and difficult to have different opinion from his superior. From different view point, this kind of people is alluded to be less initiative coworker/staff. The single word utterance tidak 'no' can be both an information giving or a refusal if the context of use is slipped off.

\section{(3) TIDAK}

Antoni seorang karyawan baru suatu perusahaan mendapat berita bahwa ada panggilan telopon untuknya. Ternyata Bapak John, pimpinan tempat ia bekerja ingin berbicara padanya.

"Ya, Pak John," kata Antoni dengan hormat dan sopannya, "Ya, Pak John... Ya, tentu saja, Pak John, ya..ya..ya, pasti Pak. Ya ...ya..ya. TIDAK, Pak John. Sinta, sang sekretaris, yang mendengar seluruh percakapan itu, sangat terkejut. "Berani benar Anda mengatakan TIDAK padanya. Apa sih yang diminta Pak John?"

"Dia tidak minta apa-apa, jawab Antoni," Dia hanya bertanya apakah saya tidak malu terus-menerus mengatakan " $\mathrm{Ya}$ ".

\section{NO}

'Antoni, a new staff of a company got news that there was a phone call for him. Apparently, it was Mr John, the head of the company that wanted to talk to him. "Yes, Sir," said Antony respectful and politely, Yes, Mr. John, yes...yes...yes..., sure Sir. Yes...yes...yes. NO, Mr. John." Shinta, the secretary who heard the whole conversation, was very surprised. "You dare to say NO to Mr. John. What is he asked you for?" "He does not ask for anything," Antoni answered. "He only ask whether I do not feel ashamed for continuously saying "Yes"."

\section{Presupposition}

Any utterance in pragmatic view point is presupposed something in which the untruthfulness of something presupposed 

will consequently make the presupposing proposition not be judged to be true or false. In case of the following, (4), a speaker should presuppose the same condition as the people/person asked if he/she wants to show his higher capability to solve the proposed problem, eating the malakamo fruit. More clearly, the speaker must also still have mother and father. This condition does not exist in (4), or is not fully aware by the interlocutors when they are asked to solve the problem by the speaker.

\section{(4) PERMAINAN "BUAH SIMALAKAMA"}

Dalam beberapa pelatihan, saya dan Pak Charris sering menggoda peserta pelatihan tentang kiat mengatasi dilema. "Bagaimana sikapmu jika menghadapi dilema seperti makan buah simalakama? Artinya jika buah itu dimakan, ibu akan meninggal, tetapi jika buah itu tidak dimakan bapak yang meninggal." Biasanya para peserta pelatihan agak kesulitan menjawab pertanyaan ini. Namun ada juga peserta yang berusaha menjawab, "Digigit, tetapi tidak dimakan, Pak." Ada pula yang menjawab, "Tidak usah dimakan, Pak, karena saya memang jengkel dengan Bapak saya yang kawin lagi." Setelah para peserta menjawab, akhirnya mereka penasaran, balik bertanya kepada kami, "Jika Bapak berdua dihadapkan pada situasi seperti kami, yaitu menghadapi dilema seperti buah simalakama, apa yang akan Bapak lakukan?" Dengan santai kami menjawab, "Kami santai saja. Seandainya kami makan, ibu kami memang sudah meninggal, seandainya tidak kami makan, Bapak kami juga sudah meninggal. Jadi kami termasuk orang yang telah mampu mengatasi dilema buah simalakama karena Bapak dan Ibu kami sudah meninggal. Kami sudah yatim piatu."

\section{THE "SIMALAKAMO FRUIT" GAME}

'In some training occasions, Mr. Charris and I often tempted the trainees about the best way of solving dilemma. "What would you do if you faced with a situation like eating a "malakamo" fruit (proverbial fruit which brings equally bad luck if someone eat it or does not eat it. If someone eats it, his/her mother would die, and would be the same to his/her father if (s)he does not). Usually the participants found it very difficult to answer this question. However, there were also some who tried to answer. "I will just bite it, but did not eat the whole fruit". And, there was also an answer "I will not eat it because I hate my father who got married with other woman." After having answered that problem, finally they feel very embittered, and asked us back. "Now, if you two, are faced with the same dilemma like eating a malakamo fruit, what would you do?" In a relaxed atmosphere we answered, "We are just relaxed. If we eat it, our mother has passed away, and if we do not eat, our mother has also passed away. So, we are people who are already able to overcome the malakamo dilemma because our parents have already passed away. We are already orphans."

Pragmatically, any utterance which contains "if condition" presupposes that the interlocutor or the speaker to which the utterance is directed would perceive it as a serious matter, and then (s)he will give a proper reaction to the content of everything conditioned. In example (5) Pak Charris's unnatural behavior and unrealistic answers are due to his perception to the utterance as an unreal matter.

\section{(5) PERMAINAN SEANDAINYA}

Saya dan Pak Charris dalam berbagai pelatihan PMKH tingkat nasional sering menggoda peserta pelatihan dengan pertanyaan. "Tuliskan apa yang akan kau lakukan seandainya saya kasih uang 100 juta rupiah?" Jawaban yang mereka tulis di kertas cukup beragam, misalnya: Saya akan pergi haji, akan membeli rumah, akan membeli sepeda motor, $d s b$. Akan tetapi, ketika saka balik bertanya, "Siapa di antara Anda yang pada baris pertama menuliskan akan bersedekah?", ternyata tidak ada 20 persen. Kondisi ini seungguh memprihatinkan. Kemudian pertanyaan saya lanjutkan, "Siapa di antara Anda yang menolak pemberian 
saya?" Ternyata tidak ada, artinya peserta cenderung tidak kritis menerima pemberian saya. Mereka saya ingatkan bahwa dalam hukum harta haruslah mempertimbangkan dari mana asal harta, dan untuk apa harta itu dipergunakan. Sebagai pembanding saya lantas bertanya pada Pak Charris. "Pak, seandainya saya beri uang 100 juta rupiah apa yang akan Bapak lakukan?" Dengan santai Pak Charris menjawab, "Akan saya bagi-bagikan dan hamburhamburkan uang itu sampai habis." Saya balik bertanya, "Lho, kalau dihabiskan, Bapak dapat apa?" Tanya saya purapura penasaran. "Nanti, kalau sudah habis, saya akan berandai-andai lagi." (Baru berandai-andai kok sudah terlalu bernafsu, apalagi kalau sungguhan ya...?)

\section{THE IF GAME}

Mr. Charris and $I$ in several PMKH national training often tempted the training participants with a question. "Write down what would you do if I gave you 100 million rupiahs?" The answers they gave were considerably various, such as: "I would go to be a pilgrim; I would buy a house; I would buy a motor car, etc." However, when I asked them further, "Who are among you preferably would donate the money?" Apparently there were less than 20\%. This condition was really apprehensive. And then I continued, "Who among you would refuse the money?" Apparently, no one. This means that the participants tend to be uncritical receiving my gifts. I warned them that Islam wealth law should consider where the wealth was from and what it was used for. For comparison I then asked Mr. Charris. "Sir, If I give you one hundred million rupiahs, what would you do?" With full of relax he answered. "I would donate and waste all the money." I asked him again pretending to be embittered. "Oh, if you waste it all, what would you get?" "Later, if the money was already wasted up, then I would suppose it again" (It is just a supposition why do you take it seriously?)

\section{Pragmatic Implicatures}

In communicative event, speaker's intention is not always asserted by the meaning of words constructing the utterance, but it can also be implicated by them. The relation between the intention and the utterance are made possible by the existence of pragmatic reasoning (Allan, 1986, 183-188; Wijana, 1996, 37-40). Pragmatic implicatures or conversational implicatures are different from entailment, which is semantic in nature. The following (6) and (7) are examples of humorous discourse that exploit pragmatic implication.

\section{(6) MENYALAKAN LILIN}

Seorang turis sedang makan. Dia bertanya kepada pemilik rumah makan tersebut:

+ "Buat apa menyalakan lilin di siang hari begini?"

- "Untuk lalat, Tuan."

+ "Wah, hebat!! Bangsa Anda memang benar-benar baik hati. Bukan Cuma manusia, lalat pun diberi penerangan sendiri."

\section{TO LIT A CANDLE}

'A tourist was eating. He asked a question to the restaurant owner:

+ What for do you light a candle in the afternoon like this?

- "for flies, Sir."

- Oh, it is terrific. Your nation is really very kind. It is not only people, even flies you give

specific lighting.'

\section{(7) PAK, ADA PESAWAT MENYERANG}

"Pak ada pesawat Inggris menyerang!" kata seorang tentara USA kepada komandannya. Lalu si komandan berkata "Tembak pesawat mereka." Lalu beberapa menit kemudian si tentara melapor lagi, "Pak, ada pesawat Belanda menyerang." Lalu si komandan berkata, "Tembak pesawatnya." Kemudian beberapa jam berselang si tentara melapor lagi, "Pak, ada pesawat Indonesia menyerang." Lalu si komandan berkata lagi, "Biarkan saja nanti juga jatuh sendiri." 
SIR, THERE IS A PLANE ATTACKING

"Sir, there is a British plane attacking!" An American soldier said to his commander. Then, the commander said, "Shoot that plane!" And a few minutes after, the soldier reported again, "Sir, there is a Dutch plane attacking". "Fire it." And, several hours after the soldier reported again, "Sir, there is an Indonesian plane attacking." "Just, don't shoot, it will fall itself"

In (6) to give lighting for flies implies that Indonesia has a serious problem which concerns in environmental health or cleanliness. Accordingly, the tourist's utterance Bangsa Anda memang benar-benar baik hati 'your nation is really very kind' is a kind of non-literal speech act because it is not intended to give a compliment, but to express an indirect insult. Meanwhile, in (7) the commander's behavior towards the Indonesian plane implies that Indonesian made plane very bad quality. This aircraft will fall itself without being shot. This proposition implies that Indonesian aerospace technology is far behind those two countries. Different from (6) and (7), the conversational implication in (8) is drawn by the front desk library staff through the book description said by the beautiful girl.

\section{(8) BUKU PALING MEMBOSANKAN}

Seorang gadis cantik mendatangi front desk perpustakaan umum. "Minggu yang lalu saya meminjam sebuah buku, tapi itu adalah buku yang paling membosankan dari semua buku yang pernah saya baca. Tidak ada cerita atau tidak jelas sama sekali, juga terlalu banyak karakter aneh!"

Penjaga perpustakaan menyahuti. "Oh, pasti Andalah yang telah membawa buku telopon kami"

\section{THE MOST BORING BOOK}

$A$ beautiful girl came to the front desk of a public library. "Last week I borrowed a book, but that was the most boring book I had ever read. There is no story or it is not clear at all. And, it has many strange characters!"
The library attendant responded, "Oh, you must be the person who took away our telephone book."

In the following (9) the pragmatic implicatures are expressed by the lecturer in which the utterance "Mohon bantuannya ditutupkan pintunya dari luar, ya?" 'Would you close the door from outside, please!" indirectly suggests that the student is not allowed to follow the lecture. This pragmatic aspect is combined with non-literal apologizing speech act but cannot be understood by the student. The student's dumbness or disrespectfulness is shown by the violation of modesty maxim, one of Leech's politeness principle sub maxims.

(9) Setiap dosen memiliki gaya unik dalam memperlakukan mahasiswa yang terlambat. Pertama versi Prof. Koento Wibisono, yaitu menyindir dengan ungkapan, "Mohon maaf. Saya sudah berani memulai sebelum Anda hadir." Biasanya mahasiswa yang tidak tahu diri justru menjawab, "Tidak apa-apa Pak, kali ini saya memaafkan." Versi kedua, versi dosen $X, d k k$., jika mahasiswa sudah benar-benar terlambat dan apalagi pakai kaos oblong dan sandal jepit, dosen $X$ akan berteriak, "Keluar...Anda tidak pantas ikut kuliah." Versi ketiga, versi Pak Ridwan, dkk. yaitu dengan mengatakan, "Bagi Saudara yang terlambat, mohon bantuannya ditutupkan pintunya dari luar, ya!" Ungkapannya halus, tetapi maksudnya tidak boleh ikut kuliah.

'Every lecturer has a unique way in treating his students who come late. The first is Prof. Koentowibisono's version. He usually teases the students by saying "I am sorry, I dare to start the lecture before you are coming." Usually the dull students will give an answer "It doesn't matter, Sir. This time I forgive you." The second version is Mr. $X$ and his friends. In the case of the students who are too late let alone they wear $T$ shirt and slippers, they will shout: "Go out, you are not proper to enter the class." The third is $\mathrm{Mr}$. Ridwan's version. "For you the late 
comer, would you close the door from outside, please!" His expression is polite, but he means the student is not allowed to follow the lecture'.

\section{Closing Remarks}

Beside the use of play on word, as what has been proved by the previous studies, the exploitation of pragmatic aspects which have higher level than those used in punning are also found in humorous discourse creating activities. Those pragmatic aspects are speech acts, presupposition, and pragmatic implicatures. Because of the data limitation and the rareness study of these pragmatic aspects, especially on presupposition and implicature category, this paper has not been able to find out yet what types of presupposition and implicatures which are always exploited by the humorous discourse creators.

\section{References}

Allan, Keith. Linguistic Meaning. Volume I. London: Routledge \& Kegan Paul, 1986.

Apte, Mahadev L. Humor and Laughter. Ithaca: Cornell University Press, 1985.

Grice, H.P. "Logic and Conversation". P. Cole \& J.L. Morgan (Eds.). Syntax and Semantics 3: Speech Acts. Pp 41-58. New York: Academic Press, 1975.

Leech, Geoffrey. Principles of Pragmatics. New York: Longman, 1983.

Noerhadi, Toety Heraty. "Kartun dan Karikatur sebagai Wahana Kritik Sosial". Majalah Ilmu-ilmu Sosial. XVI. No. 2, 1989: pp. 129-155.

Parker, Frank \& Kathryn Riley. Linguistics for Non-linguists. Singapore: Pearson., 2014.

Raskin, Victor. Semantic Mechanism of Humor. Dordrecht: D. Reidel Publishing Company, 1994. 